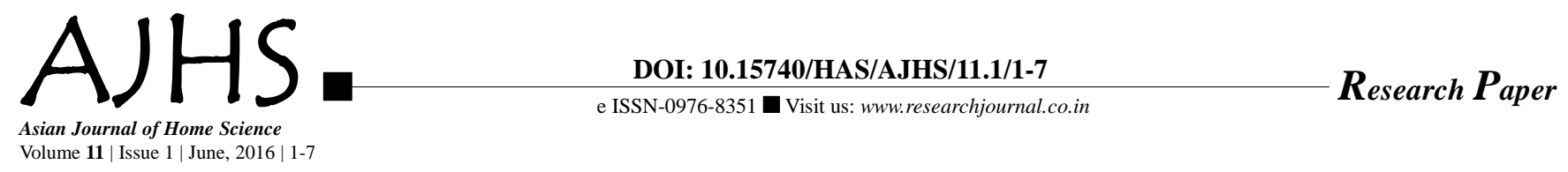

\title{
Anthropometric parameters and effect of bael (Aegle marmelos L.) on mineral content of type 2 diabetics
}

See end of the paper for authors' affiliations UTTARA SINGH

Department of Food and Nutrition, Bindeshwari Mahavidyalay, AMBEDKAR NAGAR (U.P.) INDIA

Email : usuttarasingh@gmail.com
-ABSTRACT : The selected subjects were divided into four groups viz., group I, II, III and IV having thirty subjects each. The subjects of group I was not given any treatment. The subjects of group II, III and IV were supplemented with $2 \mathrm{~g}$ of bael (Aegle marmelos L.) leaf, pulp and seed powder, respectively for a period of three month and supplementation was continued along with nutrition counseling for the next three months. The nutrition education was given for three months after fifteen days interval to the subjects of group II, III and IV through individual and group contact and gain in nutrition knowledge was assessed after the study. There was a significant decrease $(\mathrm{p} \leq 0.01)$ in calcium, phosphorus, magnesium and significant increase $(\mathrm{p} \leq 0.05)$ of zinc and iron $(\mathrm{p} \leq 0.01)$ by the subjects of group II, III and IV.

KEY WORDS: Bael, Mineral content, Type 2 diabetics

- HOW TO CITE THIS PAPER : Singh, Uttara and Kochhar, Anita (2016). Anthropometric parameters and effect of bael (Aegle marmelos L.) on mineral content of type 2 diabetics. Asian J. Home Sci., 11 (1) : 1-7, DOI: 10.15740/HAS/AJHS/11.1/1-7. 